\title{
Nörodejeneratif Hastalık Araştırmalarında Drosophila melanogaster Modeli
}

\author{
Cem HAZIR, Gamze BORA, Hayat ERDEM-YURTER
}

Hacettepe Üniversitesi Tıp Fakültesi, Tıbbi Biyoloji Anabilim Dalı, Ankara.

\section{ÖZET}

Drosophila melanogaster yașam döngüsünün kısa olması, nükleotit dizisi bilinen küçük bir genoma sahip olması, insan hastalıklarına neden olan genlerin birçoğunun ortoloğunu bulundurması, temel hücresel olayların/sinyal yolaklarının korunmuş olması ve etik problem yaratmaması gibi önemli avantajları olan omurgasız bir canlıdır. Bu avantajlar sayesinde insan hastalıklarının modellenmesi mümkün olmus ve patofizyolojilerin araştırılması, yeni genlerin ve genetik düzenleyicilerin tanımlanması, klinik çeşitlilik nedenlerinin açıklanabilmesi ve yeni tanı/tedavi geliştirme çalışmaları hız kazanmıştır. Bu derlemede Drosophila melanogaster'in model organizma olarak avantajları ve nörodejeneratif hastalıklarla ilişkili araştırmalarda kullanılmasına ilişkin bilgiler özetlenmiştir.

Anahtar Kelimeler: Drosophila melanogaster. Model organizma. Nörodejeneratif hastalık. Genetik.

Drosophila melanogaster Model in Neurodegenerative Disease Research

\begin{abstract}
Drosophila melanogaster is an invertebrate organism which has several advantages including having a short life cycle, a small genome with known sequence, orthologues of several human disease genes, conserved cellular processes/pathways without ethical concerns. Due to these advantages, human disease modellling is possible and research areas such as investigating pathophysiology, identifying new genes/modifiers, understanding the reasons of clinic variability, developing new diagnostics/therapeutics have been accelerated. In this review, advantages of Drosophila melanogaster as a model organism as well as its use in neurodegenerative diseases are summarized.
\end{abstract}

Key Words: Drosophila melanogaster. Model organism. Neurodegenerative disease. Genetics.

Drosophila melanogaster'in (D.melanogaster/meyve sineği) araştırma amaçlı kullanımı, ilk kez 1901 yılında Harvard Üniversitesi Laboratuvarları'nda W. Castle ve grubu tarafindan bildirilmiş olmasına rağmen, D.melanogaster araştırmalarının atası olarak kabul edilen ilk bilim insanı T. H. Morgan'dır ${ }^{1}$. Morgan, D.melanogaster'i model organizma olarak kullanarak, genlerin kromozomlar içerisinde yer ald1ğını kanıtlamayı başarmış, beyaz göz renginin X kromozomu üzerinde taşındığını göstererek bilim camia-

Geliş Tarihi: 06.Mayıs.2020

Kabul Tarihi: 10.Ağustos.2020

\section{Dr. Hayat ERDEM-YURTER}

Hacettepe Üniversitesi Tıp Fakültesi,

Tıbbi Biyoloji Anabilim Dalı,

Sıhhıye, Ankara

Tel: 03123052541

E-posta: herdem@hacettepe.edu.tr

Yazarların ORCID ID Bilgisi:

Cem HAZIR: 0000-0002-3139-3113

Gamze BORA: 0000-0002-4206-8332

Hayat ERDEM-YURTER: 0000-0002-5883-0643 sının dikkatinin bu modele çevrilmesini sağlamıştır. Genetik alanında yeni bir kapının açılmasına öncülük eden Morgan 1933 yılında "kromozomun kalıtımdaki rolü” ile ilgili keşiflerinden dolayı Fizyoloji ve Tıp Alanında Nobel Ödülü'ne layık görülmüştür ${ }^{2}$. Bundan sonra X 1şınlarının mutasyon oranları üzerindeki etkisi, erken embriyonik gelişimin genetik kontrolü, doğuştan gelen bağışıklığın tanımlanması, sirkadyan ritmi kontrol eden moleküler mekanizmaların aydınlatılması başta olmak üzere birçok değerli çalışmada D.melanogaster kullanılmasıyla, hücresel ve genetik mekanizmaların aydınlatılması mümkün olmuştur ${ }^{3,4}$.

\section{Model organizma olarak D. melanogaster}

Model organizmalar, insanlarla çalışmanın uygun ve etik olmadığ 1 durumlarda tercih edilen, nörodejeneratif hastalıklar, kanser, immün sistem hastalıkları, enfeksiyon hastalıkları başta olmak üzere insanlarda görülen hastalıkların altında yatan mekanizma ve patolojilerin aydınlatılması, evrimsel biyoloji çalışmalarında taksonlar arasındaki filogenetik ilişkilerin (benzerlik ve farklılıklar) belirlenmesi, gelişim 
biyolojisi çalışmalarında omurgalı gelişim sürecinin aydınlatılması, ilaç tarama ve geliştirme çalışmaları gibi farklı alanlarda laboratuvar ortamında kullanılan canlılardır. Kısa sürede hızla çoğalmaları, düşük maliyetle yetiştirilebilmeleri, insan genomu ile kıyasland1ğında daha basit bir genoma sahip olmaları, genom haritalarının çıkartılmış olması ve en önemlisi, insan hastalıklarına neden olan birçok genin model organizmalarla homoloji göstermesi, model organizmaları hastalıklarla ilgili araştırmalarda oldukça önemli kılmaktadir ${ }^{5,6}$.

Drosophilidae ailesine ait bir cins olan Drosophila'nın D.melanogaster, D.erecta, D.yakuba, D.simulans, D.santomea gibi 1500 'ün üzerinde türü olduğu bilinmektedir $^{7}$. Tür çeşitliliği çok fazla olsa da hastalık modeli çalışmalarında en sık tercih edilen D.melanogaster türünün öne çıkmasında; endemik olmamas1, dünyanın her yerinde bulunabilmesi ve kolaylıkla ulaşılabilir olması gibi temel nedenler bulunmaktadır. Ayrıca yüzyılı aşkın süredir çalışılması sayesinde anatomisinin ve fizyolojisinin çok iyi açıklanmış olması, hücre tiplerinin iyi bilinmesi, birçok genin tanımlanmasında kullanılmış olması ve ardından bu genlerin homologlarının insanlarda keşfedilmesi, bu türü diğer türlerden ayırarak ön plana çıkmasını sağlamıştır ${ }^{8,9}$. İnsan hastalıklarının aydınlatılması için transgenik farelerin model olarak kullanılması da oldukça elverişli bir yol olmakla birlikte bu farelerin oluşturulması ve analizleri pahalı/zaman alıcı olmaktadir $^{10}$. Bu nedenle, genetik manipülasyonların D.melanogaster'de olduğu gibi yaşam döngüsü daha kısa ve maliyetleri daha düşük olan modellerde gerçekleştirilmesi önemli avantajlar sağlamaktadır. D.melanogaster'in omurgalı bir canlı olmaması, kan, kemik, kıkırdak gibi bazı doku tiplerini bulundurmaması, açık dolaşım sistemine sahip olması, insana ait bazı organları bulundurmaması, akıllara insan hastalıkları ile ilişkili araştırmalar için ne kadar uygun olduğu sorusunu getirmektedir ${ }^{8}$. Buna karşılık, gen ifadesi/düzenlenmesi, hücre içi protein trafiği, sinaptogenez, hücre iskelet sisteminin işleyişi ve hücre ölümü başta olmak üzere hücre biyolojisinin temel mekanizmalarının insana benzer olduğu bilinmekte$\operatorname{dir}^{10}$. Kısa zamanda hizla çoğalabilmesi, boyutunun küçük olması (2-3 mm), genomunda değişiklik yapılabilmesi, laboratuvar ortamında kolay/düşük maliyetle yetiştirilebilmesi ve kullanımları için etik izinlere ihtiyaç olmaması, D.melanogaster'in model organizma olarak tercih edilme nedenleri arasında bulunmaktadır. 2000 yılında genom dizileme çalışmalarının tamamlanması ile insanda bulunan genlerin \%60'ının, insan hastalıklarına neden olan genlerin ise yaklaşık olarak \%70'inin D.melanogaster'de ortoloğunun bulunduğu açıklanmıştır. Bu benzerlik korunmuş bölgelerde \%80-\%90'a kadar çıkmaktadır. Bu nedenlerle, D.melanogaster insanda görülen hastalıkların modellenmesine ve araştırılmasına uygun bir model olarak kabul edilmektedir ${ }^{4,11,12}$.

\section{D. melanogaster'in Yaşam Döngüsü}

D.melanogaster metamorfoz geçiren bir canlı olup yaşam döngüsü; embriyo, larva, pupa ve ergin olmak üzere farklı gelişimsel dönemlerden oluşmaktadır. $25^{\circ} \mathrm{C}$ sicaklıkta $10-12$ gün $\left(28^{\circ} \mathrm{C}\right.$ 'de 8 gün) olan yaşam döngüsü, uygun laboratuvar koşullarında 50 güne kadar uzayabilmektedir. Gelişim süreci, sıcaklığın yanı sıra beslenme şekilleri ve laboratuvar koşullarından da etkilenmektedir ${ }^{13}$. Laboratuvar koşullarında, dişi sinek üzerinde yaşadığı besiyerine bir günde yüzlerce yumurta birakır ve 24 saatin sonunda yavruların tamamı yumurtadan çıkar. 10-12 günlük süreçte sürekli olarak besiyerinden beslenen larvalar (1. 2. ve 3 . evre larva) ortalama olarak 5. günün sonunda larva dönemini tamamlayarak pupa dönemine geçerler. (Şekil 1). Bu dönemde beslenmeye artık ihtiyaç duymayan ve besiyerinden uzaklaşarak depoladıkları besinleri kullanan pupalar, buldukları uygun bir yere tutunarak metamorfoz geçirmeye başlar ve bu sürecin ardından erginleşirler ${ }^{1,14}$.

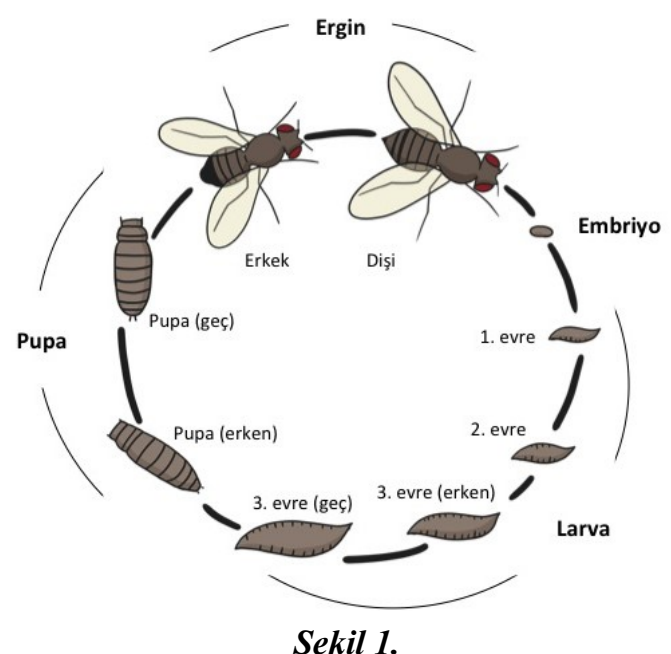

D.melanogaster'in yaşam döngüsü. Strasıyla, embriyo, larva dönemleri (1. evre, 2. evre, 3.evre), pupa ve ergin gelişimsel dönemlerinden oluşmaktadır.

\section{3. İnsan Hastalıklarının Modellemesinde D.melanogaster Kullanımı}

D.melanogaster kullanılarak insan hastalıkları modellenebilmekte ve bu sayede hastalıkların genetik ve kompleks hücresel mekanizmalarının araştırılmasına yönelik genomik ve fonksiyonel genomik çalışmalar yürütülebilmekte, ayrıca ilaç araştırmaları da gerçekleştirilebilmektedir. En sık modellenen hastalıklar arasında; kanser, kardiyovasküler sistem hastalıkları, metabolik hastalıklar, immün sistem hastalıkları, nörodejeneratif hastalıklar, diyabet ve poliglutamin hastalıkları sayılmakta, son yıllarda yaşlanma ve bağımlılık konularındaki araştırmalarda da yaygın olarak kullanılmaktadir ${ }^{11,15,16}$. 


\section{Nörodejeneratif Hastalıklar ve Drosophila melanogaster}

- Kanserler, D.melanogaster üzerinde en uzun süredir çalışılan hastalık grubudur. Kansere neden olan mutasyonun ilk olarak 1967 yilında G. Schneiderman tarafindan bu modelde keşfedilmesini takiben tümör oluşumu ve metastaza neden olan genlerin aydınlatılması amacı ile çok sayıda çalışma yapılmıştır ${ }^{17-19}$.

- Kardiyovasküler sistem hastalıklarının araştırılmasinda da bu model siklıkla kullanılmaktadır. İnsan ve D.melanogaster kalplerinin gelişim süreçlerinin hem yapısal hem de fonksiyonel benzerlikler göstermesi, kardiyovasküler hastalık araştırmalarında kullanılmasını sağlamıştır. D.melanogaster kalbinin tıpkı insan kalbinde olduğu gibi 4 odacıklı olması, sinyal yolaklarının ve kalp gelişimi için temel olan genlerin oldukça korunmuş olması, Drosophila'yı uygun bir model haline getirmiştir. Özellikle korunmuş genlerde çeşitli mutasyonlar yaratılarak kalp fonksiyonlarının araştırılması mümkün olmuştur ${ }^{20,21}$.

- D.melanogaster'de karaciğer benzeri bir organ bulunmaması bazı metabolik hastalıkları bu canl1larda çalışmayı zorlaştırmaktadır. Ancak yapılarında yağları ve şekerleri depolamak için bulundurdukları yă cisimciklerinin insan hepatositlerine benzer işlev gördüğü ve evrimsel olarak korunmuş olan insülin mekanizması tarafından düzenlendiği bilinmektedir. İnsan hepatositlerinde ifade edilen bazı genlerin homoloğunun bulunması sayesinde, D.melanogaster hepatosit hücrelerinde işlev kayb1 görülen bazı metabolik hastalıkları araştırmak üzere kullanılmaktadır ${ }^{21}$.

- Drosophila modelinde sıklıkla çalışılan diğer bir grup immün sistem hastalıklarıdır. D.melanogaster'de fagositoz, otofaji gibi mekanizmaların evrimsel olarak korunmuş olması, bakteri ve mantar enfeksiyonları sonrasında epitel bariyerler, reaktif oksijen bileşikleri ve antimikrobiyal peptitler gibi yanıtların oluşması immün sistem hastalıklarının araştırılmasına imkan vermiştir ${ }^{22}$.

\section{Nörodejeneratif Hastalıklar ve D.melanogaster}

Nörodejeneratif hastalıklar, nöron hücrelerinin yapı ve fonksiyon kaybına uğramasıyla ortaya çıkan bilişsel bozukluk, hafıza kaybı, solunum yetmezliği ya da hareket yetersizliği gibi farklı patofizyolojiler ile karakterize olan geniş bir hastalık grubudur. Alzheimer, Parkinson, Spinal müsküler atrofi (SMA), Amyotrofik lateral skleroz (ALS) ve Huntington hastalığı bu gruba örnek olarak verilebilir. Son yüzyılda bu hastalık grubunun içerdiği karmaşık mekanizmaları aydınlatmak için birçok alanda çalışmalar gerçekleştirilmiş, hasta dokusu eldesindeki zorluklar ve etik sınırlandırmalar bilim insanlarını hayvan modelleri üzerinde çalışmaya yönlendirmiştir ${ }^{23,24}$.

D.melanogaster, nörodejeneratif hastalıkların modellenmesinde kullanılmasını olanaklı hale getiren bazı avantajlara sahiptir. $\mathrm{Bu}$ avantajlar sayesinde, model organizma olarak kullanılabilmekte ve farklı araştırma yaklaşımları izlenebilmesine imkan yaratmakta$\mathrm{d} 1 \mathrm{r}^{9,25,26}$. D.melanogaster, genlerin fonksiyonlarının aydınlatılması ve bu sayede hastalıklarla ilgili temel mekanizmaların açıklanmasına katkı sağladığı gibi, hastalıkların tedavisine yönelik araştırmaların yürütülebilmesi nedeniyle translasyonel çalışmalara da katkı sağlamaktadır (Tablo I, Şekil 2). Aşağıda sık görülen bazı nörodejeneratif hastalıkların araştırılmasında D.melonogaster kullanılmasına ilişkin bilgiler özetlenmiştir.

\subsection{Spinal Müsküler Atrofi (SMA)}

SMA genellikle çocukları etkileyen, omuriliğin ön boynuzunda bulunan motor nöron kaybı ile karakterize olan ve kalıtsal bebek ölümlerinin en yaygın nedenini oluşturan nörodejeratif bir hastalıktır. Hastalık 5 q13 kromozom bölgesinde bulunan SMN1 (Survival of Motor Neuron 1) geninin homozigot delesyonu sonucunda ortaya çıkmakta ve SMN protein eksikliği SMA hastalığına neden olmaktadır. Aynı kromozom bölgesinde $S M N 1$ geninin kopyası olan SMN2 geni de bulunmakta, iki gen arasındaki birkaç nükleotitlik fark splicing hatalarına neden olarak, SMN2 gen bölgesinden fonksiyonel SMN protein üretimini de yaklaş1k \%90 oranında engellemektedir ${ }^{27-30}$.

D.melanogaster genomunun insan genomu kadar karmaşık olmaması ve çoğu insan geninin sadece bir kopyasını bulundurması bu canlıda yapılan modelleme çalışmalarını kolaylaştırmaktadır. Örneğin, D.melanogaster'in insandaki SMN1 genine oldukça benzer tek bir ortoloğa sahip olması (Smn) ve bu gen bölgesinin kolay manipüle edilebilmesi, SMA araştırmaları için uygun bir model olmasını sağlamıştır ${ }^{31}$. Diğer model organizmalardan farklı olarak, SMA'lı D.melanogaster modellerinde, anneden köken alan düşük düzeyde yabanıl tip SMN proteini bulunmakta, bu nedenle SMN yokluğunda diğer model organizmalarda görülen embriyonik letalite görülmemektedir ${ }^{25}$. D.melanogaster'in Smn geninde farkl1 mutasyonlar yaratılarak oluşturulan fenotiplerde, hasta bireylere benzer olarak anormal motor davranışlar, sinaptik ve nöromüsküler kavşak bozuklukları gözlenmiştir. Örneğin, DmSMN ${ }^{73 \text { Ao }}$ mutant Drosophila modelinde SMN proteinin azalması sineklerde nöromüsküler kavşak bölgelerinde bozukluğa neden olmuştur ${ }^{32}$.

D. melanogaster modelinde, SMN proteininin kas dokusundaki önemini göstermek de mümkün olmuştur. Chang ve arkadaşlarının yaptıkları çalışmada, SMN proteininin ifadesi kaslarda ve nöron hücrelerinde baskılandığında, her iki dokudaki azalışın birbirlerin- 


\section{Hazır, ark.}

den bağımsız olarak erken ölüme neden olduğu, SMN proteininin nöronlar gibi kas hücrelerinde de mutlaka ifade edilmesi gerektiği gösterilmiştir. Ayrıca, SMN proteininin omurgalı canlılarda olduğu gibi Z disklerinde alfa aktin ile kompleks oluşturduğu saptanmış ve bu bulgular SMN proteininin kas dokusuna özel bir fonksiyonunun olabileceğini düşündürmüştür ${ }^{31,33}$.

SMA'da önemli olan başka bir konu da aynı tip mutasyonu bulunduran hastaların fenotiplerinin birbirlerinden çok farklı olmasıdır. Bu farkı açıklamak üzere, hastalığın seyrini değiştirebilecek aday genlerin ve SMN proteininin etkileşimde olduğu proteinlerin araştırılmasında D.melanogaster modelinden yararlanılmaktadır. Örneğin; D.melanogaster'in fibroblast büyüme faktörü (FGF) reseptör geni olan breathless geninde mutasyon yaratılması, Smn ifadesinin RNA interferans ile baskılandığı durumda görülen nöromüsküler kavşak hatalarını şiddetlendirmiştir. Ayrica, Smn ifadesi RNA interferans ile baskıland1ğında FGF sinyal yolağında rol alan bazı proteinlerin transkript düzeylerinin azalması da SMA'da FGF sisteminin önemli olabileceğini göstermiştir ${ }^{34}$.

\subsection{Amyotrofik Lateral Skleroz (ALS)}

ALS üst ve alt motor nöronların dejenerasyonu ile karakterize edilen, nörodejeneratif bir hastalıtır. Sporadik ve ailesel olmak üzere iki tipi bulunan hastalık, en sık 60-85 arası yaş grubunda görülmektedir 9,35,36. ALS vakalarının \%90-95'i sporadik, \%5'i aileseldir. Hastalığa neden olan mutasyonlar ilk olarak süperoksit dismutaz (SOD1) geninde tanımlanmış ve bunu izleyen y1llarda hastalığa neden olan (TDP43, VAPB, FUS/TLS, C9orf72, TBK1, CHCHD10, PFN1 vb) çok sayıda gen bildirilmiştir ${ }^{37}$.

SOD1 geni, hücreleri oksidatif strese karşı koruyan, toksik süperoksit radikallerini hidrojen peroksit ve oksijene dönüştüren bakır bağımlı bir enzimi kodlamaktadır. D.melanogaster ile yapılan bir çalışmada, aşırı ifade edilen SOD1 proteininin motor nöronlarda biriktiği ve hasara neden olduğu gösterilerek ALS'nin protein birikimi hastalıkları grubuna dahil olabileceği ilk kez düşünülmüştür ${ }^{38}$.

İnsanlarda ailesel ALS'ye neden olan SOD1 geni mutasyonlarından A4V ve G85R, D.melanogaster nöronlarında ifade ettirildiğinde tırmanma bozuklukla-

Tablo I. D. melanogaster'in model organizma olarak kullanılmasındaki avantajlar/dezavantajlar ve nörodejeneratif hastalıklarla ilgili çalışmalara sağladığı katkılar.

\begin{tabular}{|c|c|}
\hline Avantajlar & Temel Bilgi Üretilmesi \\
\hline $\begin{array}{l}\text { - Kısa yaşam döngüsü ve süresinin } \\
\text { olması }\end{array}$ & - Gen fonksiyonlarının anlaşılması \\
\hline - Bakım maliyetlerinin pahalı olmaması & - Genetik düzenleyicilerin tanımlanması \\
\hline - Etik problemlerin olmaması & - Moleküler ağların açıklanması \\
\hline $\begin{array}{l}\text { - Temel hücresel olayların ve sinyal } \\
\text { yolaklarının korunmuş olması }\end{array}$ & Translational Yararlar \\
\hline $\begin{array}{l}\text { - Küçük bir genomunun olması ve } \\
\text { genom dizisinin bilinmesi }\end{array}$ & $\begin{array}{l}\text { - Hastalık patolojilerinin açıklanması } \\
\text { - Klinik cesitliliğin anlassılması }\end{array}$ \\
\hline - Genom manipülasyonun kolaylığı & - Yeni tanı yaklaşımlarının geliştirilmesi \\
\hline $\begin{array}{l}\text { - Transgenik modellerin hızlı ve ucuz bir } \\
\text { şekilde oluşturulması }\end{array}$ & $\begin{array}{l}\text { - Tedavi yaklaşımlarının geliştirilmesi } \\
\text { - İlaç geliştirilmesi }\end{array}$ \\
\hline $\begin{array}{l}\text { Kompleks merkezi sinir sisteminin, } \\
\text { kan beyin bariyerinin ve } \\
\text { nöromüsküler sistemin varlığı }\end{array}$ & \\
\hline Dezavantajlar & \\
\hline $\begin{array}{l}\text { - Omurgalı olmaması } \\
\text { - Insandaki tüm doku (ör; kan, kemik, } \\
\text { kıkırdak) ve organları (ör; karaciğer) } \\
\text { bulundurmaması } \\
\text { - Insandaki tüm hastalıkların } \\
\text { modellenememesi }\end{array}$ & \\
\hline
\end{tabular}




\section{Nörodejeneratif Hastalıklar ve Drosophila melanogaster}

rına neden olmuştur. Ayrıca SOD1 proteinin nöronlarda yaşa bağlı olarak biriktiği ve glia etrafında stres yanıtı oluşturduğu gözlenmiştir. Bu bulgular daha sonra yapılacak olan çalışmalarda nöron-glia etkileşimlerinin incelenmesinin önemli olacağı fikrini doğurmuştur ${ }^{39}$.
İnsanlarda ALS'nin patolojik bir göstergesi olarak kabul edilen mitokondri işlev bozukluğuna SOD1 mutasyonlarının neden olabileceği hipotezi öne sürülmüş ve Drosophila üzerinde test edilmiştir. SOD1 geni D83S mutasyonu, SOD1 proteininin çinko iyonlarına bağlanmasını engelleyerek hücresel toksisiteye neden olmaktadır. Transgenik bir model oluşturularak,

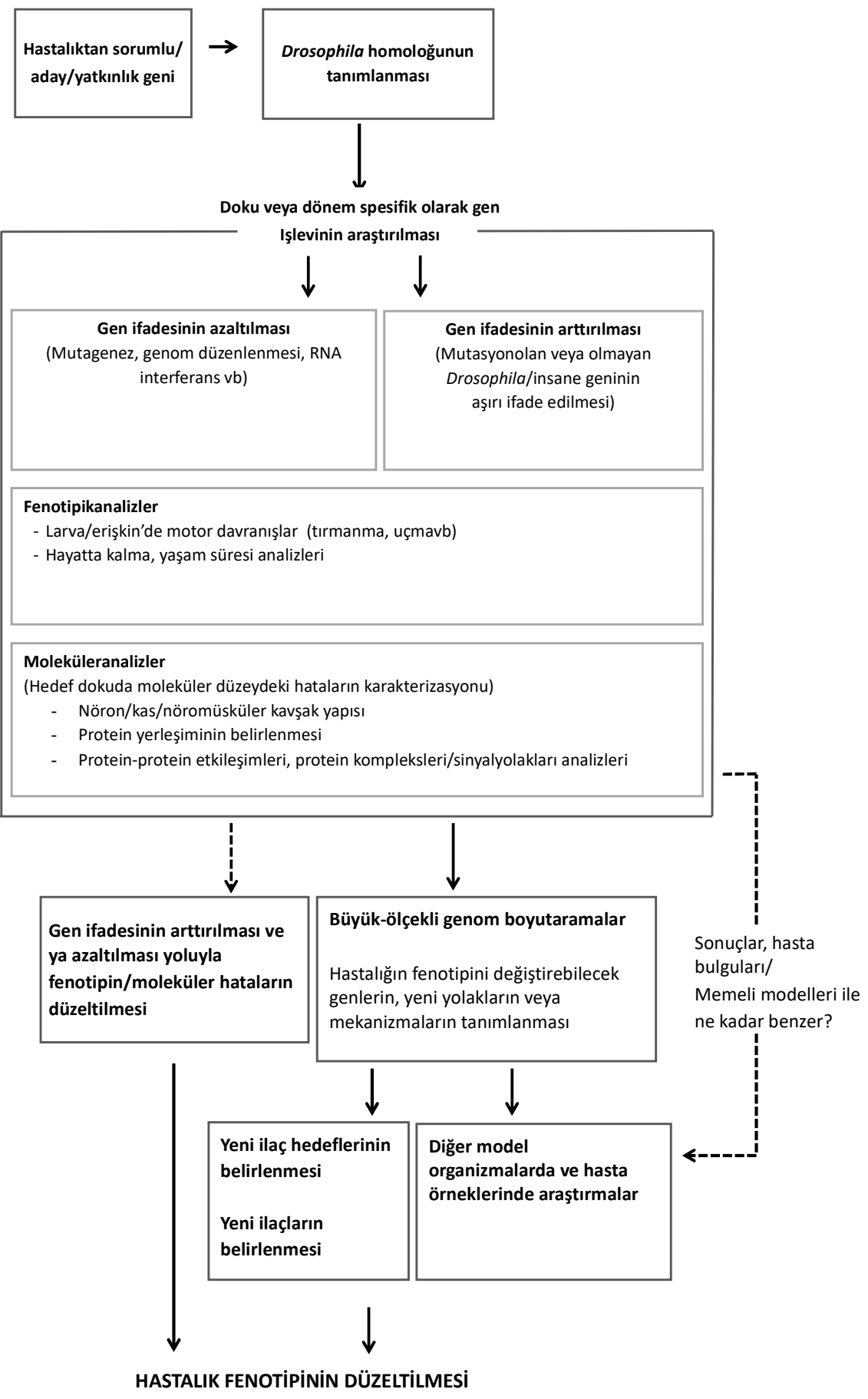

Sekil 2.

Drosophila modeli kullanılarak yürütülen çalışmalarda izlenen bazı stratejik yaklaşımlar. 


\section{Hazır, ark.}

çinko iyonlarına bağlanması engellenen insan mutant SOD1 proteini Drosophila'da ifade ettirilmiş ve mutant SOD1 ile mitokondri işlev bozukluğu arasındaki ilişkiyi destekleyen kanıtlar elde edilmiştir. Yap1lan çalışmalar uçmayı sağlayan kaslarda mitokondri yapılarının bozulduğunu, mutantların beyinlerindeki ATP miktarının kontrole göre azaldığını, vücutlarındaki ATP miktarının ise mutant ve yabanıl tipte değişmediğini göstermiştir. Böylece SOD1 geni D83S mutasyonunun, nöronlarda ATP miktarını azalttığı ve mitokondri işlev bozukluğuyla ilişkili olduğu görüşü desteklenebilmiştir ${ }^{40}$.

Vesicle-associated membrane protein associated protein $B / C(V A P B)$ gen mutasyonlar1 otozomal dominant geçişli ALS'ye neden olmaktadır. Drosophila'daki ortoloğunda yaratılan P58S mutasyonunun nöronlarda aşırı ifadesi, larvaların nöron hücrelerinde mikrotübül organizasyonunu bozulmasına, nöron ölümüne, larva hareketinin azalmasına neden olmuştur. Ayrıca mutantlardaki sinaptik taşınımın bozulmasının, VAPB proteininin aşırı ifade edilerek düzeltilebilmesi, bu proteinin sinaptik fonksiyonda görevi olduğunu düşündürmüştür ${ }^{41,42}$.

TDP43 proteininin ALS patogenezindeki toksik rolü, Drosophila'da fonksiyon kayb1 (loss of function) ya da fonksiyon kazanımı (gain of function) mutasyonları oluşturularak incelenmiştir. Yabanıl tip TDP43 proteininin nöronlarda baskılanması, erişkin sineklerde yaşam süresinin kısalmasına ve hareket yeteneklerinde azalmaya, aşırı ifadesi ise erişkin sineklerin yaşam süresinin kısalmasının yanı sıra hem larva hem erişkin sineklerin hareket yeteneğinin azalmasına neden olmuştur. Drosophila beyninde TDP43 proteininin hem baskılanması hem de aşırı ifadesi durumunda, nöron ve akson kayıpları oluşması, TDP43 proteininin fonksiyonel kaybında olduğu gibi fonksiyon kazanımında da toksik etki yaratabileceğini göstermiştir ${ }^{43}$.

ALS'de fenotipi değiştirebilecek genleri araştırmak amaciyla da Drosophila modelinden yararlanılmaktadır. Örneğin TDP43 genindeki Q331K mutasyonunun retinada yarattığı toksisitenin, Ataxin 2 geninin aşırı ifade edilmesiyle arttığı, baskılanması ile ise azaldığ gösterilmiş ve aday düzenleyici gen olarak kabul edilmiştir $^{44}$.

\subsection{Parkinson Hastalığı (PD)}

Parkinson hastalığı (PD), dopaminerjik nöron hasar1/kaybı nedeni ile motor fonksiyon hataları gözlenen, alfa sinüklein birikimlerinin görüldüğü Lewy cisimciklerinin oluşması ile karakterize nörodejeneratif bir hastalıktır ${ }^{45}$. Vakaların çoğunun sporadik olduğu bilinmekle birlikte, hastalığın ortaya çıkmasında genetik ve çevresel faktörler de rol oynamaktadır. Ubikitinproteozom sistemi tarafindan yanlış katlanan proteinler, Lewy cisimcikleri içerisinde anormal protein birikimi, oksidatif stres, dopaminerjik nöronların kaybı, anormal protein yıkımı, mitokondri işlev bozukluğu, hastalığın ortaya çıkmasında rol oynayan bazı anomaliler olarak bilinmektedir ${ }^{46-48}$. Hastalığa neden olan LRRK2, ATP13A2, GBA, SNCA, PINK1, Omi-Htra2, $D J-1, U C H L 1$ gibi çok sayıda gen tanımlanmıştır. Bu genlerden bazılarının ortoloğu D.melanogaster'de bulunmaktadır (örneğin, PINK1, DJ-1, LRRK2) ${ }^{49,50}$.

Bugüne kadar Parkinson hastalığının mekanizmasını çözümlemek, hastalığa neden olan protein etkileşimlerini aydınlatmak, hastalık fenotipini değiştiren genetik düzenleyicileri tanımlamak, hatalı hücresel mekanizmalarla hastalık fenotipini düzelten ilaç hedeflerini belirlemek ve çevresel etkileri incelemek amacıyla D.melanogaster'de çeşitli modeller yaratılmıştır ${ }^{10,51}$. Örneğin, Parkin ve Pink1 mutant Drosophila modellerinin oluşturulması, Parkin ve Pink1 arasındaki ilişkiyi ve mitokondri hasarındaki rollerini anlamakta önemli olmuştur. Parkin mutant Drosophila'da, yaşam süresinin kısalması, uçmada görev yapan kasların dejenerasyonu, hareket problemleri, kas hücrelerinde mitokondri yapı bozuklukları ve oksidatif strese karşı duyarlılık gözlenmiştir. Pink1 mutantlarda da kas dejenerasyonu ve benzer mitokondri hatalarının görülmesi Parkin ve Pinkl'in aynı moleküler yolakta görev aldığını düşündürmüştür ${ }^{52,53}$. Pinkl mutant Drosophila'da görülen fenotipik bulgular, Parkin geninin aşırı ifade edilmesi ile düzeltilirken, Parkin mutantların bulgularının Pinkl geninin aşırı ifadesi ile düzeltilememesi, rol aldıkları yolakta Pink1 geninin Parkin'in yukarısında yer aldığını göstermiştir. Pink1 ve Parkin mutant Drosophila'da mitokondri hasarı görülmesi, mitokondri morfolojinin düzenlenmesinde rol oynayan proteinlerin araştırılmasına da imkan sağlamıştır. Örneğin, mitokondri fisyon proteini olan Drp1 proteininin ifadesinin arttırılmasıyla mitokondri hasarı düzeltilebilmesi mümkün olmuştur ${ }^{54}$.

İnsan alfa sinüklein ve mutantları Drosophila dopaminerjik nöronlarında ifade ettirildiğinde nöron kaybı saptanmış, bu bulgu mutasyon içermesinden bağımsız olarak alfa sinüklein protein miktarındaki fazlalığını toksik etki yaratarak dopaminerjik nöron kaybına neden olabileceğini düşündürmüştür. İnsan Hsp70 şaperon proteininin ifadesi sağlandığında ise alfa sinüklein birikimi tarafindan indüklenen dopaminerjik nöron hasarı kısmen düzeltilebilmiştir. Hsp70'in alfa sinüklein toksisitesi üzerindeki etkisini araştırmak amacıyla Drosophila'da Hsp70 proteinin ortoloğu olan Hsc4 şaperon proteininin trifosfat bağlanma domaininde mutasyon yaratılmıştır. Mutant Hsc4 ve alfa sinüklein proteinin birlikte ifade edildiği bu modelde dopaminerjik nöron kaybının artması, şaperon aktivitesinin yükseltilmesinin Parkinson tedavisinde etkili olabileceğini göstermiştir ${ }^{55}$. Bir başka çalışmada da, Drosophila'ların şaperon aktivitesini indükleyen geldanamisin ile beslendiklerinde dopaminerjik nöronlarda alfa sinüklein tarafindan indüklenen toksisiteden korundukları gösterilmiştir ${ }^{56}$. 
Sporadik Parkinson'un çevresel faktörler ve gen-çevre etkileşimleri sonucunda meydana geldiği düşünülmektedir. Drosophila'da 6-hidroksidopamin, rotenon ve parakuat gibi nörotoksinler uygulanarak hastalığın sporadik formları modellenmiştir. $\mathrm{Bu}$ modellerde, Parkinson hastalığında görülen Lewy cisimciklerinde protein birikimi olmamakla birlikte, nörodejenerasyon ve mitokondri yapısında bazı değişiklik/bozuklukların ortaya çıktığı gözlenmiştir ${ }^{57}$.

\subsection{Alzheimer Hastalığ}

Alzheimer, ilerleyen hafiza kaybı ile sonuçlanan, korteks ve hipokampüste nöron kaybına neden olan bilincin ve davranışların etkilendiği nörodejeneratif bir hastalıktır. Hastalığın patogenezinde hücre dışı amiloid plak birikimi, sinaptik bozulmalar ve nöron ölümleri görülmektedir ${ }^{58-61}$. Amiloid beta plak birikimi Alzheimer hastalığının en temel nedenleri arasındadır. Plaklar, beta sekretaz enziminin öncül amiloid proteinini kesmesiyle meydana gelen amiloid beta peptitlerinin birikmesiyle oluşturulmaktadır. Amiloid beta birikimi, tau-mikrotübül bağlanmasının kontrol bozukluğunu da içeren nörotoksik mekanizmaları aktive etmektedir. Tau, mikrotübüllere bağlanarak stabilite sağlayan bir proteindir. Hiperfosforile olması durumunda tau-mikrotübül etkileşimi bozulmakta, tau birikmekte ve nörofibriler düğümler (neurofibrillary tangles) oluşmaktadır ${ }^{62,63}$.

D.melanogaster modelinde tau ve plazma amiloid beta protein (Aß42) genlerinin aşırı ifade edilmesi ile hastalarda gözlenen nöron kaybı, yaşam süresinin kısalması, lökomotor hareketin bozulması gibi fenotipik değişimler yaratılabilmiştir. Drosophila retinasında normal ve mutant tau proteinin aşırı ifadesi retina hücrelerinin ölmesine ve kaba göz fenotipine $(R E P)$ neden olmuştur. Bu fenotip sineklerde genetik etkileşimleri taramak için sıklıkla kullanılmaktadır. Örneğin, glikojen sentaz kinaz $3 \beta$ (GSK3 $\beta$ ) geninin ortoloğu olan shaggy'nin, tau'nun etkisini modifiye ettiği bu fenotip ile saptanmıştır ${ }^{64}$.

Transgenik Drosophila modelleri ilaç araştırmalarının hızlı, etkili ve ekonomik bir şekilde yapılmasını da mümkün k1lmaktadır. Örneğin, A $\beta 40$ ve A $\beta 42$ proteinlerinin nörodejenerasyondaki rolünün ve toksisiteye olan etkilerinin araştırılması için transgenik Drosophila modellerinden yararlanılmıştır ${ }^{65}$. A $\beta 40$ ve A 342 peptitleri ile oluşturulan plaklar, yaşa bağlı nörodejenerasyona ve erken ölümlere neden olmuş ve oluşturulan bu modeller, $\beta$-sekretaz inhibitör tarama çalışmaları için kullanılmıştır. Aday inhibitör bileşiklerle beslenen transgenik Drosophila larvalarında $\beta$ sekretaz enzim aktivitesi azaltılarak, yaşa bağlı nörodejenerasyon fenotipinin normale dönmesi ve erken ölümlerin sonlanması sağlanmıştır ${ }^{66}$.

\section{Sonuç/Tartışma}

Morgan'ın laboratuvarında beyaz gözlü mutantları keşfetmesiyle dikkatleri çeken D.melanogaster, genetik araştırmalar alanında yeni bir kapı açmıs, nörodejeneratif hastalıklar dahil olmak üzere birçok hastalığın patofizyolojisini, hastalık etiyolojisini etkileyen mekanizmaların aydınlatılmasını ve semptomlarının anlaşılmasını sağlamış ve halen sağlamaya devam etmektedir. Hastalıkla ilişkili temel moleküllerin ve sinyal yolaklarının birçoğunun insandan önce D.melanogaster'de keşfedilmesi, moleküler genetik ve hücre biyolojisi alanlarındaki keşiflere hız kazandırmış, model canlıların önemini arttırmıştır. Çalışmalarda, fare, sıçan gibi insana evrimsel açıdan daha yakın model organizmalarla birlikte Drosophila modelinin kullanılması ile farklı türler arasında korunmuş düzenleyici genlerin/moleküler yolakların tanımlanması mümkün olabilmekte, ortak bulgular aynı moleküler değişikliklerin insanlarda olma olasılığını güçlendirmektedir. Drosophila modelinin günümüzde hastalıklara ilişkin birçok bilinmeyeni gün yüzüne çıkarma potansiyelinin bulunması, bundan sonraki y1llarda yeni teknolojiler geliştikçe tıp alanındaki sorularımıza cevap arayışımızda önemli roller üstlenmeye devam edeceğinin açık göstergesidir.

\section{Teşekkür}

Şekil çizimindeki katkılarından dolayı Nazlı Tunalı'ya teşekkür ederiz.

\section{Etik Kurul Bilgisi:}

Yazımızın türünün derleme olması nedeniyle etik kurul onayına gerek bulunmamaktadır.

\section{Kaynaklar}

1. Jenning BH. Drosophila - a versatile model in biology and medicine. Materials Today. 2011;14:190-195.

2. The Nobel Price in Physiology or Medicine (1933). https://www.nobelprize.org/prizes/medicine/1933/summary/

3. Tolwinski NS. Introduction: Drosophila- a model system for developmental biology. J Dev Biol. 2017;5:9.

4. Allocca M, Zola S, Bellosta P. The fruit fly, Drosophila melanogaster: the making of a model (Part I). In: Perveen FK, (eds). Drosophila melanogaster: Model for Recent Advances in Genetics and Therapeutics. Rijeka, Croatia: InTech;2018:113130.

5. Ankeny RA, Leonelli S. What's so special about model organisms. Studies in History and Philosophy of Science. 2011;42:314-323.

6. Hedges SB. The origin and evolution of model organisms. Nature. 2002;3:838-849.

7. Bachli G. TaxoDros: The database on taxonomy of Drosophilidae, (taxodros.uzh.cs). (1999-2006). 


\section{Hazır, ark.}

8. Gonzalez C. Drosophila melanogaster: a model and tool to investigate malignancy and identify new therapeutics. Nature Rev. 2013;13:172-183.

9. McGurk L, Berson A, Bonini NM. Drosophila as in vivo model for human neurodegenerative disease. Genetics. 2015;201:377402.

10. Sang TK, Jackson RG. Drosophila models of neurodegenerative disease. The Journal of the American Society for Experimental NeuroTherapeutics. 2005;2:438-446.

11. Pandey UB, Nichols CD. Human disease models in Drosophila melanogaster and the role of the fly in therapeutic drug discovery. Pharmacol Rev. 2011;63:412-431.

12. Baenas $\mathrm{N}$, Wagner AE. Drosophila melanogaster as an alternative model organism in nutrigenomics. Genes Nutr. 2019;14:1-11.

13. Moreno MA, Farr CL, Kaguni LS, Garesse R. Drosophila melanogaster as a model system to study mitochondrial biology. Methods Mol Biol. 2007;372:33-49.

14. Flatt T. Life history evolution and the genetics of fitness components in Drosophila melanogaster. Genetics. 2020:214:3-48.

15. He Y, Jasper H. Studying aging in Drosophila. Methods. 2014;68:129-133.

16. Ryvkin J, Bentzur A, Krispil SZ, Ophir GS. Mechanism underlying the risk to develop drug addiction, insights from studies in Drosophila melanogaster. Front Physiol. 2018;9:112.

17. Yamaguchi M, (eds). Drosophila models for human diseases. 1st edition. Singapore: Springer; 2018.

18. Potter CJ, Turenchalk GS, Xu T. Drosophila in cancer research an expanding role. Trends in Genetics. 2000;16:33-39.

19. Villegas SN. One hundred years of Drosophila cancer research: no longer in solidute. Disease Models and Mechanisms. 2019; $12: 1-5$

20. Bodmer R. The gene tinman is required for specification of the heart and visceral muscles in Drosophila. Development. 1993;118:719-729.

21. Allocca M, Zola S, Bellosta P. The fruit fly, Drosophila melanogaster: modeling of human diseases (Part II). In Perveen FK, (eds). Drosophila melanogaster: Model for Recent Advances in Genetics and Therapeutics. Rijeka, Croatia: In Tech; 2018:131-156.

22. Bergman P, Esfahani SS, Engstrom Y. Drosophila as a model for human diseases-focus on innate immunity in barrier epithelia, Curr Top Dev Biol. 2017;121:30-66.

23. Gitler AD, Dhillon P, Shorter J. Neurodegenerative disease: models, mechanisms and a new hope. Dis Models Mech. 2017; 10:499-502.

24. Peng C, Trojanowski JQ, Lee VM. Protein transmission in neurodegenerative disease. Nature. 2020;16:199-212.

25. Aquilina B, Cauchci RJ. Modelling motor neuron disease in fruit flies: Lessons from spinal muscular atrophy. $J$ Neurosci Methods. 2018;310:3-11.

26. Ugur B, Chen K, Bellen HJ. Drosophila tools and assays for the study of human diseases, disease models and mechanisms. Dis Model Mech. 2016;9:235-244.

27. Cartegni L, Krainer AR. Disruption of an SF2/ASF-dependent exonic splicing enhancer in SMN2 causes spinal muscular atrophy in the absence of SMN1. Nature. 2002;30:377-384.

28. Lefebvre S, Burglen L, Reboullet S, ve ark. Identification and characterization of a spinal muscular atrophy-determining gene. Cell. 1995;80:155-165.

29. Melki J, Lefebvre S, Burglen L, ve ark. De novo and inherited deletions of the $5 \mathrm{q} 13$ region in spinal muscular atrophies. Science. 1994;264:1474-1477.
30. Groen EJN, Talbot K, Gillingwater TH. Advances in theraphy for spinal muscular atrophy: promises and challenges. Nature Rev Neurol. 2018;14:214-224.

31. Kreipke RE, Kwon YV, Shcherbata HR, Baker HR. Drosophila melanogaster as a model of muscle degeneration disorders. Current Topics in Developmental Biology. 2017;121:83-109.

32. Chang HC, Dimlich DN, Yokokura T, ve ark. Modelling spinal muscular atrophy in Drosophila. PLoS ONE. 2008;3:1-18.

33. Lloyd TE, Taylor JP. Flightless flies: Drosophila models of neuromuscular disease. Ann N Y Acad Sci. 2010;1184:1-25.

34. Sen A, Yokokura T, Kankel MW, ve ark. Modeling spinal muscular atrophy in Drosophila links Smn to FGF signaling. $J$ Cell Biol. 2011;192:481-495.

35. Martin S, Khleifat AA, Chalabi AA. What causes amyotrophic lateral sclerosis. F1000Res. 2017;6:1-10.

36. Blacher E, Bashiardes S, Shapiro H, ve ark. Potential roles of gut microbiome and metabolites in modulating ALS in mice. Nature. 2019;572:474-480.

37. Tortarolo M, Coco DL, Veglianese P, ve ark. Amyotrophic lateral sclerosis a multisystem pathology: Insights into the role of TNF $\alpha$. Mediators of Inflammation. 2017;2017:1-16.

38. Casci I, Pandey UB. A fruit fly endeavor: Modeling ALS in the fruitfly. Brain Res. 2015;1607:1-28.

39. Watson MR, Lagow RD, Xu K, Zhang B, Bonini NM. A drosophila model for amyotrophic lateral sclerosis reveals motor neuron damage by human SOD1. J Biol Chem. 2008;283:24972-24981.

40. Bahadorani S, Mukai ST, Rabie J, ve ark. Expression of zincdeficient human superoxide dismutase in Drosophila neurons produces a locomotor defect linked to mitochondrial dysfunction. Neurobiol Aging. 2013;34:2322-2330.

41. Chai A, Withers J, Koh YH, ve ark. $h V A P B$, the causative gene of a heterogeneous group of motor neuron diseases in humans, is functionally interchangeable with its Drosophila homologue DVAP-33A at the neuromuscular junction. Hum Mol Genet. 2008; 17:266-280

42. Ratnaparkhi A, Lawless GM, Schweizer FE, Golshani P, Jackson GR. Drosophila model of ALS: Human ALSassociated mutation in VAP33A suggests a dominant negative mechanism. PLoS ONE. 2008;3:1-13.

43. Diaper DC, Adachi Y, Lazarou L, ve ark. Drosophila TDP-43 dysfunction in glia and muscle cells cause cytological and behavioural phenotypes that characterize ALS and FTLD. Hum Mol Genet. 2013;22:883-3893.

44. Elden AC, Kim HJ, Hart MP, ve ark. Ataxin-2 intermediatelength polyglutamine expansions are associated with increased risk for ALS. Nature. 2010;466:1070-1077.

45. Radhakrishnan DM, Goyal V. Parkinson's disease: A review. Neurol India. 2018;66:26-35.

46. Yamaguchi M, (eds). Drosophila models for human diseases. 1 st edition. Singapore: Springer; 2018

47. Baroli B, Loi E, Solari P, ve ark. Evaluation of oxidative stress mechanisms and the effects of phytotherapic extracts on Parkinson's disease Drosophila PINK1B9 model. FASEB J. 2019;33:11028-11034

48. DeMaagd G, Philip A. Parkinson's disease and its management. P \& T. 2015;40:504-532

49. Wang D, Tang B, Zhao G, ve ark. Dispensable role of Drosophila ortholog of LRRK2 kinase activity in survival of dopaminergic neurons. Mol Neurodegener. 2008;3:1-7

50. Poole AC, Thomas RE, Andrews LA, ve ark. The PINK1/Parkin pathway regulates mitochondrial morphology. Proc Natl Acad Sci U S A. 2008;105:1638-1643.

51. Xiong Y, Yu J. (2018) Modeling Parkinson's disease in Drosophila: What have we learned from dominant traits?. Front Neurol. 2018;9:1-15 


\section{Nörodejeneratif Hastalıklar ve Drosophila melanogaster}

52. Pesah Y, Pham T, Burgess $H$, ve ark. Drosophila parkin mutants have decreased mass and cell size and increased sensitivity to oxygen radical stress. Development. 2004;131:2183-2194

53. Greene J., Whitworth A., Kuo I, ve ark. Mitochondrial pathology and apoptotic muscle degeneration in Drosophila parkin mutants. Proc Natl Acad Sci U S A. 2003;100:40784083

54. Deng H, Dodson M, Huang H, Guo M. The Parkinson's disease genes Pink1 and Parkin promote mitochondrial fission and/or inhibit fusion in Drosophila. Proc Natl Acad Sci $U S A$. 2008;105: 14503- 14508.

55. Auluck PK, Chan HY, Trojanowski JQ, Bonini NM, Lee VM. Chaperone supression of alpha synuclein toxicity in a Drosophila model for Parkinson's disease. Science. 2002;295:865-868

56. Auluck PK., Bonini NM, Meulener MC. Mechanism of supression of alpha synuclein neuro toxicity by geldanamycin in Drosophila. J Biol Chem. 2005;280:2873-2878

57. Soriano VM, Paricio N. Drosophila models of Parkinson's disease: Discovering relevant pathways and novel therapeutic strategies. Parkinsons Dis. 2011; 2011:1-14

58. Khanahmadi M, Farhud DD, Malmir M. Genetic of Alzheimer's disease: A narrative review article. Iran $\mathrm{J}$ of Public Health. 2015;44:892-901
59. Yamaguchi M, (eds). Drosophila models for human diseases. 1 st edition. Singapore: Springer; 2018.

60. Ulep MG, Saraon SK, Mclea S. Alzheimer disease. The Journal for Nurse Practitioners. 2018;14:129-135

61. Tue NT, Dat TQ, Ly LL, Anh VD, Yoshida H. Insights from Drosophila melanogaster model of Alzheimer's disease. Front Biosci. 2020;25:134-146

62. Tan FHP, Azzam G. Drosophila melanogaster: Deciphering Alzheimer's disease. Malays J Med Sci. 2017;24:6-20

63. Buhl E, Higham JP, Hodge JJL. Alzheimer's disease-associated tau alters Drosophila circadian activity, sleep and clock neuron electrophysiology. Neurobiol Dis. 2019;130:1-9

64. Prüßing K, Voigt A, Schulz JB. Drosophila melanogaster as a model organism for Alzheimer's disease. Mol Neurodegener. 2013;8:2-11

65. Iijima K, Liu HP, Chiang AS, ve ark. Dissecting the pathological effects of human Aß40 and Aß42 in Drosophila: A potential model for Alzheimer's disease. Proc Natl Acad Sci U S A. 2004;101:6623-6628

66. Greeve I, Kretzschmar D, Tschäpe JA, ve ark. Age-dependent neurodegeneration and Alzheimer-amyloid plaque formation in transgenic Drosophila. J Neurosci. 2004;24:3899-3906. 
